NIH's budget strategy of attempting to stabilize the number of new and renewing competitive awards at about 5,000 remains virtually intact. Furthermore, Congress has replaced much of the money for research training grants which the Office of Management and Budget wished to cut.

Technically, the 4 per cent reduction is only a provisional figure, valid up to March. Unable to agree on a detailed appropriations bill, Congress agreed last month to a "continuing resolution"' for the next three months. In practice, however, since debate on the budget for the 1983 fiscal year begins later in January - and no substantial objection to the provisional 1982 totals are expected from the White House - the 4 per cent reduction is likely to run to September.

It has been a confused budget year for NIH. Before leaving office in January, President Carter proposed a biomedical budget for the institutes of $\$ 3,770$ million, a figure left virtually untouched in the Reagan Administration's budget review in March and representing an increase of about 5.6 per cent over 1981 . However, realizing that the budget deficit in general was going to be much larger than initially anticipated, the Reagan Administration in September recommended an across-theboard cut of 12 per cent, which would have reduced the NIH budget to $\$ 3,310$ million.

The net result of last month's continuing resolution is that, rather than having to reduce the number of new awards for competing research projects to 4,230 , as the proposed September revisions would have required, NIH expects to be able to make almost 4,800 of these during the current financial year. This is little short of the 5,000 which was adopted as a goal two years ago, following several years in which the number of such awards, which are provided to support investigator-initiated research projects, had fluctuated widely.

The budget resolution procedure thwarted a move supported by several legislators in the House of Representatives to direct additional research funds to three institutes: the National Institute of General Medical Sciences, the National Institute of Allergy and Infectious Diseases, and the National Institute of Child Health and Human Development. These were felt to be suffering more than the others from the squeeze on research funds, in terms of the quality of the research projects that were being refused funding.

NIH officials are optimistic that the 1983 budget which $\mathrm{Mr}$ Reagan submits to Congress next month will again contain a small increase for NIH. Secretary of Health Mr Richard Schweiker is said to have argued successfully against major cuts in biomedical research that had been proposed by the Office of Management and Budget.

David Dickson

\title{
New director chosen for NIH
}

\section{Washington}

Dr James B. Wyngaarden, chairman of the department of medicine at Duke University in North Carolina, is expected to be nominated by President Ronald Reagan as the new director of the US National Institutes of Health (NIH) in Bethesda, Maryland.

Although yet to be formally announced - and subject to approval by the US Senate - Dr Wyngaarden's appointment is thought to have been unofficially approved by the White House, and the delay in making an announcement is the result of the lengthy security and financial checks which all presidential appointees undergo.

Dr Wyngaarden would probably be a popular choice at NIH's headquarters, and with the biomedical research community in general. Those who know him say they expect him to provide strong leadership and vigorously to defend the $\$ 3,600$ million research budget of NIH, the principal source of federal funding for biomedical research in the United States.

Dr Wyngaarden has been a close professional colleague of $\mathrm{Dr}$ Donald Fredrickson, who resigned as $\mathrm{NIH}$ director last July after six years in the post. Together with Dr John B. Stanbury, the three were co-editors of an influential collection of essays, The

Metabolic Basis of Human Diseases. First published in 1960, the book is about to go into its fifth edition, and is considered by many to be a classic in its field.

Dr Fredrickson said last week that he had "no doubt" that Dr Wyngaarden would fill the NIH position extremely well. "He is a good physician, an excellent scientist, and understands the institutional aspects of medical research very well; I have every confidence that he will be an excellent director'.

A graduate of the University of Michigan, Dr Wyngaarden is no stranger to Washington science policy circles. He was a consultant to the Office of Science and Technology Policy between 1966 and 1972, and a member of the President's Science Advisory Committee from 1972 until its abolition in 1973. Before his appointment at Duke, he was professor of medicine and chairman of the department at the University of Pennsylvania from 1965 to 1967.

NIH scientists hope that a speedy confirmation of Dr Wyngaarden's appointment will help to accelerate other senior appointments at NIH. Six of the twelve institutes lack a permanent director, and approving the new appointments will be one of the first tasks awaiting the new director.

David Dickson

\section{Molecular biology Trimming costs}

Molecular biologists who are used to relying on the European Molecular Biology Organisation for providing fellowships and other useful means of mobility within Europe may have to pay closer attention to the politics of its budget next December for the 1982 budget has seen a 3 per cent fall (in real terms) for the second year running.

The secretary of the organization, Dr John Tooze, says that management costs have been trimmed to the absolute minimum, and that for 1982 cuts will have to be undertaken in the EMBO programme itself. The 1982 budget will be DM 3.5 million $(£ 825,000)$, numerically 8 per cent above last year but 3 per cent below EMBO's calculated inflation figure.

The EMBO scheme accounts for $\mathbf{4 0 0}$ fellowships in any year, plus 40 courses and workshops and a small lectureship programme - which often takes prominent American and other visiting scientists around Europe on a lecture tour. It is this lecture programme which is likely to be cut this year.

If the budget were to be cut again for a third year, the fellowships and workshops would be hit, says Tooze. Then the smaller countries (of the 17 member states of EMBO) would certainly object. These countries are probably the main beneficiaries of the programme, and they in fact constitute a two-thirds majority of states on the council which votes the budget of EMBO each year. Decisions can be taken by such a majority but the remaining states - Britain, France, Germany and Italy contribute nearly 60 per cent of the budget. The danger is that if the small countries kick up a fuss, the big four could refuse to pay. This year a compromise has been reached. It may not be so easy next year.

Robert Walgate

\section{Microbial collections \\ Bugs in hazard}

Once again, a British microbial culture collection is threatened by lack of funds. At the end of last year the Ministry of Agriculture, Fisheries and Food announced its intention to withdraw support for the National Collection of Industrial Bacteria housed at the Torry Research Station in Aberdeen. This is the third time in two years that culture collections have been threatened by withdrawal of funds. The Brewery Research Foundation and the agriculture ministry have already stopped supporting the national yeast culture collection and the Commonwealth Mycological Institute and Natural Environment Research Council have said that they wish to cut support for the national fungi collection.

Although the problems of the yeast and fungal collections have been at least 
temporarily solved, the threat to the industrial bacteria collections has stimulated the UK Federation of Culture Collections to urge that a single government agency should take over responsibility for all of Britain's ten national collections. The problem is that the collections currently share seven sponsors, not all of which ascribe high priority to their sponsorship.

In the event, the industrial bacterial collection may also be saved, though not necessarily to the satisfaction of its users. The most likely outcome is that the agriculture ministry, the collection's sole sponsor, will relinquish responsibility to the University of Aberdeen from next April. Negotiations are under way for transferring the collection to the university's company, which handles the commercialization of research relevant to industry. The idea is that the collection should eventually operate as a commercial concern.

Under the arrangements now being discussed the ministry would pay the university for running the collection, although payment would be considerably less than current running costs of about $£ 200,000$ a year. Savings would be achieved largely by reducing the number of staff from twelve to about seven. Still to be determined are the university's commission on continuing business, the ministry's initial grant and what should be charged for consultancy and services. Although the proposal would save the collection, the microbiological community, which fears that commercialization could jeopardize some of the services currently on offer and increase costs to users, is glum about the prospects.

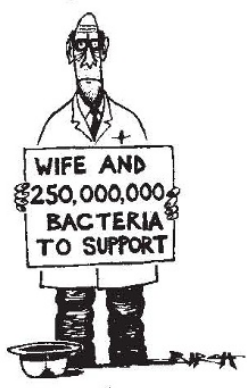

Last year, an inter-research council committee was set up to deal with the funding problems of culture collections as and when they arise. But the UK Federation of Culture Collections now argues that the committee's remit is too narrow. Together with three learned societies, including the Society for General Microbilogy, the federation is hoping to persuade one government agency to take over responsibility for all ten microbial collections and to coordinate the formulation of a national policy for genome conservation including plant and animal cell lines as well as microbial cultures. As yet, however, no obvious agency has come forward, although the federation is hopeful that a meeting with the Department of Industry early in the year will be fruitful.

Judy Redfearn

\section{Stanford University At the helm}

\section{Palo Alto}

When biologist Donald Kennedy became Stanford University's eighth president in August 1980, he pledged strong support for the humanities. Now, more than a year later, he has delivered; $\$ 5.6$ million in gifts and grants have helped to create a new Humanities Center. From other contributions, eight professorships have been endowed.

Nevertheless, some faculty members remain sceptical of Kennedy's efforts to make support for the arts and humanities comparable with that for the sciences. One humanist complains that too much time is spent on training and not enough on students' personal development. He thinks that a university should be primarily concerned with values. $\mathrm{He}$ is waiting for Kennedy to enunciate his values and to exert intellectual leadership. "You can buy administrative ability", the disgruntled professor believes.

During Kennedy's spell in Washington as Commissioner of the Food and Drug Administration, he won wide respect for his administrative ability. Although he denies rumours about his own political ambitions, he still travels frequently to the capital.

He says that one of his objectives is to improve government understanding of the kinds of problems research universities face and about national science policy. $\mathrm{He}$ has the experience and the contacts to talk about these matters in the right places.

And lean, six-foot-one Kennedy believes that Stanford will be able to continue as a first-rate centre of basic research in spite of federal research cutbacks this year of 2 or 3 per cent. $\mathrm{He}$ is a self-avowed "relentless optimist". Nevertheless, he worries about reduced support for student financial aid. More than half of Stanford's 12,800 students receive scholarships. Research and training should go hand in hand, a truth not always recognized by the Reagan Administration, Kennedy says.

Kennedy remains doubtful that private support for universities will help to cover the gap created by diminished federal funding. Although private support for research has grown, it amounts to only 3.5 per cent of Stanford's total research budget of $\$ 130$ million a year.

The success of Stanford's own venture in commerce is necessarily still unclear. Last month, 71 companies signed licences for the gene-splicing and cloning patents developed by Stanford geneticist $\mathrm{Dr}$ Stanley Cohen and University of California biochemist Dr Herbert Boyer. Both scientists have made over their share of royalties to their universities. Initially, the licensing will yield $\$ 710,000$ annually, but the iong-term potential could be much higher.

In the face of his campus's burgeoning

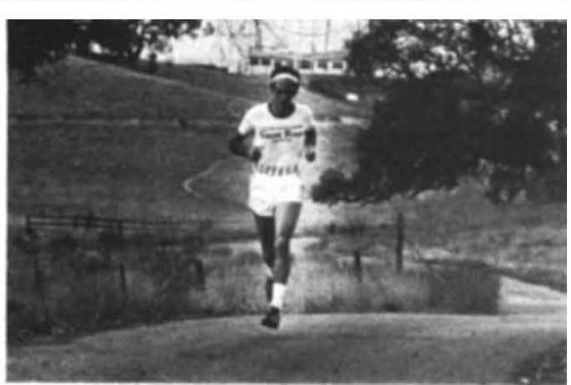

Donald Kennedy keeps ahead

biotechnology, Kennedy spends much of his time on the ethical questions of proprietary research. He has organized a conference in March with administrators, faculty scientists and representatives of industry to establish possible guidelines for the future. His own interest in science policy stems from his work as a founder of the human biology programme at Stanford. He was chairman of the biology department in 1965-72. His colleagues consider him a brilliant administrator and a fine scientist, able to articulate his views clearly.

Although a member of the National Academy of Sciences, Kennedy does not expect to return to the laboratory. His speciality is the neurophysiology of behaviour. He continues to work on two unpublished papers about how connections among nerve cells are responsible for fixed behavioural acts.

Meanwhile, he enjoys his contact with students and giving guest lectures, as well as advising eight freshmen. He has a reputation as an outstanding and entertaining lecturer. Thus, to illustrate man's evolution from the primitive fish Amphioxus, he will sing to the tune of "It's a long way to Tipperary",

Goodbye fins and gill slits,

Hello teeth and hair.

It's a long way from Amphioxus,

But we came from there.

Kennedy is blessed with enormous energy. But some of his faculty grumble that he is too enthusiastic, that he is also too generous, and that he resorts too quickly to resolving disagreements with university funds.

Students nevertheless like him. Graduating seniors have repeatedly asked him to address them. He attends more than 24 sherry parties annually in student dormitories.

Will his present enjoyment of his leadership of Stanford last? A close associate suggests that within five years Kennedy will start to think about a new post. It takes that long for the excitement and pleasure of the office to begin to dissipate.

At present it is possible to find Stanford's president at 6.30 a.m. each Tuesday and Friday morning running four miles over hilly terrain. Those who wish to discuss problems or to offer suggestions are welcome to join him. Most of his colleagues agree that one has to be pretty swift to outrun him.

Charlotte K. Beyers 